DOI: $10.15290 /$ bsl.2020.16.12

\author{
Agnieszka Januszkiewicz \\ Wydział Filologiczny \\ Uniwersytet w Białymstoku \\ e-mail: agnieszkajanuszkiewicz@o2.pl \\ ORCID: 0000-0003-2487-4995
}

\title{
Siła sprawcza afektu. O balladzie Czaty Adama Mickiewicza
}

Ballada Adama Mickiewicza Czaty nie cieszyła się dużym zainteresowaniem historyków literatury, być może ze względu na przynależność gatunkową, która nie zachęcała do głębszego namysłu nad utworem. Gatunek ten bowiem zagarnięty przez poetę u progu romantyzmu już wtedy - w Balladach $i$ romansach - zdawał się osiągnąć postać paradygmatyczną, czy to w sferze wyznaczników formalnych, tematycznych, czy ideowych. Jeśli interesowała więc badaczy romantyczna ballada, skupiali się na cyklu z 1822 roku, późniejsze wiersze balladowe Mickiewicza nie przedstawiały już dla nich większej wartości ${ }^{1}$. Napisane w 1828 roku $^{2}$ podczas pobytu w Rosji Czaty mogły

1 Publikacje poświęcone gatunkowi ballady to m.in.: Ballada polska, oprac. C. Zgorzelski, I. Opacki, Wrocław 1962; Niemiecka ballada romantyczna, oprac. Z. Ciechanowska, Wrocław 1963; P. Pluta, Polska ballada gotycka, Warszawa 2017. O Balladach i romansach pisało wielu autorów, a wśród nich Z. Stefanowska, Próba zdrowego rozumu. Studia o Mickiewiczu, Warszawa 1976; K. Cysewski, O „Balladach i romansach” Mickiewicza, Słupsk 1987; B. Dopart, Mickiewiczowski romantyzm przedlistopadowy, Kraków 1992.

2 Czesław Zgorzelski datował powstanie Czatów na przełom 1827 i 1828 roku. Cz. Zgorzelski, Uwagi edytorskie, w: A. Mickiewicz, Dzieła wszystkie, wiersze 18125-1829, t. 1, cz. 2, oprac. Cz. Zgorzelski, Wrocław 1972, s. 278. Siemion Łanda natomiast, weryfikując informacje zebrane przez Zgorzelskiego, skłaniał się ku twierdzeniu, że ballada powstała w drugiej połowie czerwca 1828 roku. S. Łanda, Jak Odyniec redagowat "Czaty” Mickiewicza: z "Kroniki życia i twórczości Mickiewicza: 1824-1829”, „Pamiętnik Literacki”1982, z. 1/2, s. 227. 
im się wydawać dziełem wtórnym, stworzonym bez istotnego powodu, na marginesie ważkich dokonań literackich. Wydaje się, że również odmienność „ballady ukraińskiej” na tle ballad „litewskich” sprzyjała traktowaniu omawianego wiersza jako ciekawostki, wyróżniającej się jedynie niespotykaną dotąd w twórczości Mickiewicza przestrzenią geograficzną, specyficzną żywiołowością i oryginalnym sposobem budowy wersyfikacyjnej (anapest, strofa. tzw. mickiewiczowska). $Z$ takiego podejścia wynikała sugestia, że mamy tu do czynienia jedynie $\mathrm{z}$ wprawką literacką, zabawą słowami oraz rytmem i nic ponadto.

Lucylla Pszczołowska, autorka jednego z nielicznych artykułów poświęconego omawianej balladzie - Potęa metrum. O puszkinowskim przekładzie "Czat" - za rzecz pewną, nie wymagającą objaśnień, uznaje, że Czaty napisane zostały w tonie „żartobliwym”3. Badaczka rozpatruje utwór w kontekście rosyjskich eksperymentów wersyfikacyjnych (m.in. Wasilija Żukowskiego). Jej zdaniem podtytuł „ballada ukraińska” stanowi główny element wyznaczający lekkość tonu wiersza. Zawiera się w nim sugestia, że Czaty są stylizacją, a stylizacja zazwyczaj wiąże się z humorystycznym lub ironicznym dystansem dzieła do wzorca. Określenie „ukraińska” oznacza taką balladę, która zawiera zestaw cech uchodzących za typowe dla tego regionu czy raczej dla wyobrażeń na jego temat. Mickiewicz napisał więc tekst, który wystylizował na utwór wywodzący się z ukraińskiej tradycji kulturowej. Chciał pobawić się gatunkiem od pewnego czasu już przez niego nie wykorzystywanym, który przyniósł mu rozgłos w kraju i wywołał tzw. balladomanię. Jak wynika $\mathrm{z}$ analizy Pszczołowskiej, właśnie stylizowany charakter wiersza przyciągnął uwagę Aleksandra Puszkina, który dokonał jego tłumaczenia na język rosyjski.

Opinie formułowane o Czatach $\mathrm{w}$ dawniejszych publikacjach również dotyczyły przede wszystkim strony formalnej utworu. Według Wacława Borowego sytuacja fabularna i konstrukcje bohaterów ballady miały drugorzędne znaczenie i pełniły jedynie funkcję służebną w stosunku do wyrazistej rytmiki ${ }^{4}$. Borowy doceniał wirtuozerię wiersza i świadome podejście poety do kwestii stylistycznego artyzmu. Podobną interpretację proponował Juliusz Kleiner, eksponując wersyfikację utworu. Ponadto jednak, pisząc o okolicznościach jego powstania, odczytał balladę jako pochwałę miłości i młodości, która wynikała, jak sądził, z dobrego stanu emocjonalnego poety w czasie

3 L. Pszczołowska, Potęga metrum. O puszkinowskim przekładzie "Czat”, „Pamiętnik Literacki” 2001, z. 3, s. 172 .

4 W. Borowy, Improwizacje, utwory towarzyskie i wirtuozerskie, w: tegoż, O poezji Mickiewicza, wyd. 2 uzup., Lublin 1999, s. 190. 
tworzenia wiersza. Tok utworu miał zmierzać do aprobaty tego, co pierwotne w uczuciowości, a co za tym idzie - szczere i prawdziwe 5 .

Do powyższych uwag warto jeszcze dodać, że poeta śledził uważnie rozwijający się w Warszawie ruch teoretyczny. I stamtąd więc mógł czerpać zachętę do ćwiczeń wersyfikacyjnych, wszystko po to, aby osiągnąć jak największą sprawność w tej dziedzinie. Dowiódł jej ogłaszając tomik sonetów. Innego rodzaju osiągnięciem formalnym stały się ballady Czaty i Trzech Budrysów - w obu wierszach Mickiewicz zastosował zupełnie nowy - anapestowy - zestrój metryczny ${ }^{6}$. Starania poety miały na celu wydobycie energii życiowej, płynącej w poezji, w Czatach jednak wyraźny i żywiołowy rytm nowej anapestowej strofy wykorzystał, by przedstawić ciąg zdarzeń prowadzących do nieuniknionej katastrofy.

Omówione interpretacje wyraźnie uprzywilejowują techniczne walory Czatów, upodrzędniając wobec nich fabułę wiersza, jego dramaturgię, koncepcję bohaterów. Albo też jak u Kleinera prowadzą ku biografizmowi. Czy przywołany tu kierunek interpretacji rzeczywiście wyczerpuje warte zainteresowania odczytania tej ballady? Sądzę, że nie. Jeśli pomyśleć nad przedstawioną $\mathrm{w}$ utworze sytuacją fabularną, podjąć próbę odkrycia motywacji bohaterów i nazwania tego, co się między nimi dzieje w wymiarze emocjonalnym, można doszukać się całkiem poważnego przesłania wiersza. Wszystko, co w nim najciekawsze i najbardziej znaczące, rozgrywa się bowiem wśród afektów, emocji, uczuć, które ujawniają się w relacjach między bohaterami.

Literatura romantyczna jest niezwykle bogata, jeśli na nią spojrzeć jako na zapis czy inscenizację międzyludzkich interakcji. Relacje tego rodzaju zachodzą na różnych poziomach ludzkiego istnienia, angażując cały jego wymiar psychofizyczny. Do niedawna kwestie związane z emocjonalnością w odniesieniu do literatury XIX-wiecznej wydawały się już dobrze rozpoznane. Nowsze tendencje $w$ humanistyce, takie jak zwrot intensywny czy też bujny rozwój badań w dziedzinie psychologii i antropologii społecznej umożliwiają przyjrzenie się tym zagadnieniom ponownie, z użyciem nowoczesnych narzędzi, a co za tym idzie, uzyskać ogląd od dawniejszego bardziej zniuansowany.

5 J. Kleiner, Dalsze zdobywanie nowych terenów artyzmu, w: tegoż, Mickiewicz, wyd. 2 popr., t. 2, cz. 1, Lublin 1997, s. 162.

6 W. Borowy, Improwizacje, utwory towarzyskie i wirtuozerskie, w: tegoż, O poezji Mickiewicza, s. $189-190$. 
Mimo że romantycy - jak nikt chyba przed nimi - docenili emocjonalną sferę natury ludzkiej i podjęli zainteresowanie tym, co wydawało się groźne z punktu widzenia racjonalistów i zdroworozsądkowców, bo mogło zwieść na poznawcze manowce, prowadzić ku wewnętrznemu i społecznemu chaosowi, to musiało minąć jeszcze wiele lat, aby mogły powstać modele opisu teoretycznego, umożliwiające pełniejsze zrozumienie ich koncepcji bez ograniczania bogatej problematyki emocjonalnej do funkcji wyznacznika ówczesnej estetyki czy elementu pejzażu ideowego ${ }^{7}$.

Wydaje się, że odświeżające spojrzenie na emocjonalność romantyczną może polegać na tym, by nie ograniczając się do pytania, co i jak odczuwa romantyk albo jakie rodzaje uczuć tworzą paradygmat romantyczny, więcej uwagi poświęcić dynamice relacji międzyludzkich przedstawianych w literaturze romantycznej i przez nią projektowanych. W taki właśnie sposób proponuję spojrzeć na balladę Czaty.

Niewiele wiadomo o okolicznościach, w jakich powstała i źródłach inspiracji. Piszący o niej historycy literatury tylko domyślali się, kiedy i gdzie Mickiewicz mógł usłyszeć opowieść, która stała się fabularną kanwą ballady. Na przełomie 1824 i 1825 roku poeta znalazł się na Ukrainie, przebywając drogę z Petersburga do Odessy. Zatrzymał się w Steblowie - majątku rodziny Hołowińskich. Informacje na ten temat podał Michał Witkowski w artykule Dookoła zagadki steblowskiej, ale wizytę rozpatruje głównie pod kątem jej znaczenia konspiracyjnego jako rezultat nawiązywania kontaktów z dekabrystami. Niewiele wiadomo o literackich inspiracjach, jakich mógł przysporzyć Mickiewiczowi pobyt $\mathrm{w}$ domu rozmiłowanego w literaturze i historii Ukrainy Hermana Hołowińskiego. Witkowski zwraca jedynie uwagę na obraz steblowskiej lipy utrwalony potem $\mathrm{w}$ Panu Tadeuszu ${ }^{8}$. Do wizyty poety w Steblowie nawiązywał wcześniej Juliusz Kleiner w jednym z przypisów, którymi opatrzył analizowaną w monografii Mickiewicz balladę Czaty. Pojawiła się tam informacja, jakoby istniało przekonanie, że właśnie w domu Hołowińskich Mickiewicz poznał historię małżeńskiej zdrady, która doprowadziła do śmierci wojewody. Kleiner nie ujawnił jednak żadnych źródeł na potwierdzenie tego przypuszczenia. Za bardziej prawdopodobne sam uznał zresztą powiązanie powstania ballady z wyjazdem poety do Odessy. Główną

\footnotetext{
7 Przykładami prac traktujących o uczuciowości romantycznej w jej tradycyjnym ujęciu są książki: Goraczka romantyczna Marii Janion i antologia Miłość romantyczna Marty Piwińskiej, które już tytułami wskazują na rodzaj omawianej problematyki. Nowe miejsce nauki o afektach i emocjach opisuje Ryszard Nycz we Wstępie do tomu pokonferencyjnego poświęconego affective studies pod tytułem Kultura afektu - afekty w kulturze. Humanistyka po zwrocie afektywnym.

8 M. Witkowski, Dookoła zagadki steblowskiej, „Pamiętnik Literacki” 1956, t. 47, Zeszyt specjalny, s. 349-395.
} 
inspiracją Mickiewicza miała być opowieść hrabiego Henryka Rzewuskiego, zasłyszana podczas wspólnie odbytej podróży na Krym9.

Akcja utworu dotyczy czwórki bohaterów, doprowadzających przez swoje niekontrolowane porywy do dramatu, którego finałem będzie śmierć jednego z nich. Wojewoda odkrywa niewierność swojej młodej żony i postanawia zemścić się na kobiecie i jej kochanku z pomocą sługi - kozaka o imieniu Naum. Czaty rozpoczyna scena z wojewodą w roli głównej, który pod wpływem wielkiego wzburzenia wchodzi do pokojów swojej żony, aby przekonać się o jej nieobecności.

Wprost zostają nazwane emocje władające bohaterem w momencie zawiązania akcji. „Wściekłość i trwoga” rozpoczynają teatr nieokiełznanych żywiołów wewnętrznych, które w niedługim czasie doprowadzą do morderstwa. Będzie to zabójstwo w pewnym stopniu uzasadnione, jednak popełnione $\mathrm{z}$ pobudek niełatwo poddających się interpretacji i ocenie. Warto zaznaczyć $\mathrm{w}$ tym miejscu łączność ballady $\mathrm{z}$ antycznymi pojęciami litości i trwogi, których odczuwanie miało prowadzić do wywołania w odbiorcy katharsis. Wprowadzona przez Mickiewicza zmiana jednego z elementów („wściekłość” w miejsce „litości”) zaburza działanie skodyfikowanego przez Arystotelesa procesu oczyszczenia, przynosząc nieprzewidywalne, drastyczne skutki. Bez przeżycia litości nie można bowiem doznać wyzwolenia od niszczących sił. „Wściekłość i trwoga” prowadzą natomiast ku zgubie, oczyszczenie nie nastąpi, a skumulowane emocje ujdą $\mathrm{w}$ sposób tak gwałtowny, jak nagły jest dźwięk wystrzału w cichości wieczornego ogrodu.

Elżbieta Sarnowska-Temeriusz w artykule O katharsis - raz jeszcze pisze, że wśród niezliczonych prac na temat definiowania tej kategorii można wyodrębnić takie, które określają katharsis jako składnik poetyki tekstu dramatycznego oraz takie, w których jest ona traktowana jako działająca na poziomie odbiorcy właściwość tragedii antycznej ${ }^{10}$. W Czatach realizuje się jakaś trzecia możliwość. Autor zdaje się zastanawiać nad różnicą między katharsis antyczną a jej niemożliwością w konfliktach nowożytnych. Do tradycji teatru antycznego Mickiewicz odwoływał się w II części Dziadów, kojarząc ją z teatralnością typu operowego. Przypomnę, że romantycy uważali operę za sztukę absolutną, bo łączącą wszystkie formy artystycznego wyrazu (muzykę, słowo i obraz) oraz kontynuującą tradycję dramatu

9 J. Kleiner, Dalsze zdobywanie nowych terenów artyzmu, w: tegoż, Mickiewicz: dzieje Konrada, t. 2, cz. 1, wyd. 2 popr., Lublin 1997, s. 162.

10 E. Sarnowska-Temeriusz, O "katharsis" - raz jeszcze, „Pamiętnik Literacki” 1980, z. 4, s. 244. 
antycznego ${ }^{11}$. Można więc założyć, że balladowe sformułowanie „wściekłość i trwoga" jest celową trawestacją katarktycznej „litości i trwogi”, aby przez kontrast do niej pokazać świat bez litości, a w konsekwencji i bez katharsis, ale zarazem przez tę aluzję usytuować balladowe zdarzenia w kontekście tragedii antycznej.

Zdarzenia w Czatach zdają się rozgrywać na scenie teatralnej. Sposób narracji podkreśla teatralny charakter utworu i przypomina dzielenie tekstu na sceny możliwe do wystawienia. Balladowy narrator nie opowiada zdarzeń, które zaistniały dawno temu, lecz zdaje się towarzyszyć bohaterom krok w krok, ma więc zdolność zmieniania miejsca obserwacji. Raz towarzyszy wojewodzie, by za chwilę przysłuchiwać się z bliska miłosnym wyznaniom młodzieńca i dokładnie przytaczać jego słowa. Narrator z przejęciem mówi o tym, co się dzieje. Nie pomija rejestrowania zewnętrznych oznak stanów emocjonalnych. Dostrzega na przykład drżenie rąk wojewody, kiedy ten odkrył nieobecność żony w sypialni: „Wzrok opuścił ku ziemi i rękami drżącemi / Siwe wąsy pokręca i duma" ${ }^{12}$.

Nie można przy tym odmówić narratorowi intencji oceniającej. Wybieranie przez niego sformułowania mają wpłynąć na reakcję czytelnika. Takim wartościującym słowem jest "łeb” w zakończeniu ballady: „I ugodził w sam łeb - wojewody". Do znaczenia tego słowa w wierszu przyjdzie mi jeszcze powrócić ${ }^{13}$.

Juliusz Kleiner stwierdzał, że poeta zrezygnował w balladzie $\mathrm{z}$ budowania napięcia i grozy za pomocą typowych dla romantycznej ballady narzędzi literackich, a zastąpił je skąpym opisem scenerii i wyrazistym oraz pochłaniający rytmem ${ }^{14}$. W Czatach nie odnajdziemy obrazów przyrody, które tchną tajemniczością i żywo reagują na losy bohaterów. Nie ma tu też „dziwów" ani wydarzeń fantastycznych. Wszystko, co wiemy o świecie przedstawionym, mieści się $w$ ramach relacji międzyludzkich i jest zredukowane do absolutnego minimum. W dramat kochanków i małżonków nie ingerują siły przyrody, broniące porządku świata, jak to się działo w Balladach $i$ romansach. Wojewoda nie zostaje ukarany przez żadną tajemniczą moc - karę wymierza pogardzany przezeń sługa - Naum.

\footnotetext{
11 Zob. M. Sokolska, Opera a dramat romantyczny, Mickiewicz - Krasiński - Słowacki, Kraków 2009.

12 A. Mickiewicz, Czaty, w: tegoż, Dzieła wszystkie, wiersze 1817-1825, t. 1, cz. 2, oprac. C. Zgorzelski, Wrocław 1971, s. 64.

13 Tamże.

14 J. Kleiner, Dalsze zdobywanie nowych terenów artyzmu, s. 165-166.
} 
Od Wojewody trzeba zacząć, żeby pojąć, jak to się stało, że kozak pociągnął za spust. Jest to zdradzony mąż, a przy tym zapalczywy i mściwy starzec, którego zachowanie popycha akcję w kierunku końcowego aktu zabójstwa. Doznaje on skrajnych emocji - „wściekłość i trwoga” nie są tu istotne tylko jako element odsyłający do kontekstu teatru antycznego, ale przede wszystkim mają znaczenie $\mathrm{w}$ charakterystyce bohatera. $\mathrm{W}$ początkowym fragmencie ballady wojewoda jawi się czytelnikowi jako postać posiadająca ludzkie rysy, budząca nawet współczucie: „Odchyliwszy zasłony, spojrzał w łoże swej żony, / Pojrzał, zadrżał, nie znalazł nikogo. / Wzrok opuścił ku ziemi i rękami drżącemi / Siwe wąsy pokręca i duma". Drżenie rąk - fizyczny objaw silnego pobudzenia - może być powodem, dla którego bohater chce się posłużyć Naumem jako zabójcą kochanków. Drżącą ręką sam nie mógłby precyzyjnie wycelować z broni. Oprócz wściekłości, spowodowanej odkryciem zdrady, towarzyszy mu trwoga, czyli jedna $z$ najsilniejszych odmian strachu. Czego aż tak się boi? Chyba nie utraty miłości żony, która zgodziła się na ślub ze względów materialnych, jak się za chwilę czytelnik dowie od czyniącego jej wyrzuty kochanka. Czyżby było to przeczucie postanowienia, które wojewoda za chwilę podejmie? Albo może przeraża go zuchwałość kochanków i jej następstwa dla prestiżu i pozycji społecznej wojewody? Jedno wystąpienie przeciwko władzy zwykle pociąga za sobą następne. Można domniemywać, że wojewoda boi się ośmieszenia jako zdradzany mąż, utraty posłuchu osób od niego zależnych. Kobieta, która została żoną w zamian za korzyści materialne, popełniała $\mathrm{w}$ mniemaniu mężczyzny największą zbrodnię nie uznając autorytetu męża, podważając jego władzę i udając się na schadzkę z kochankiem. „Wściekłość” odczuwa wojewoda z powodu zdrady, "trwoga” ogarnia go na myśl o tym, co z tej zdrady wyniknie. Od doznania gwałtownego wstrząsu szybko przechodzi do planowania zemsty. Targające nim emocje potrafi natychmiast przekształcić w logicznie ułożony plan. W starcu łączy się pierwotna siła doznań wewnętrznych - afektów z racjonalnie umotywowanym działaniem. Naum zostanie wyznaczony na wykonawcę śmiercionośnych strzałów. Najpierw ma zginąć kochanek, potem wiarołomna żona, która nim umrze, powinna zobaczyć śmierć ukochanego i uświadomić sobie, co i dlaczego spotka za chwilę również ją samą. Dlaczego wojewoda nie chce zabić żony własnymi rękami? Może dlatego, co już zostało powiedziane, że drżenie rąk nie pozwoli mu precyzyjnie oddać strzałów. Ale jest możliwe inne wyjaśnienie: posłużenie się kozakiem pozwala na usankcjonowanie kary, nadanie czynowi formalnego, prawnego wręcz charakteru. Wojewoda nie chce, by zabójstwo stało się osobistą zemstą czy skrytobójstwem, ale pragnie nadać mu rangę wyroku za zdradę, dzięki czemu od- 
zyska nadszarpnięty autorytet. Poza tym nieposłuszeństwo żony chce sobie zrekompensować poczuciem absolutnej władzy nad kozakiem - bezwolnym wykonawcą jego woli.

Chociaż badacze skupiali się głównie na wersyfikacji Czatów, zdarzało im się napomknąć coś o kwestii emocji w związku z tym wierszem. I tak Wacław Borowy przyporządkował poszczególnym bohaterom ballady emocje, jakie budzą $w$ odbiorcach, przypisując im pozytywne lub negatywne wartości. Według niego jedynie wojewoda jawi się jako postać wyraźnie negatywna. Jego postępowanie wywołuje w czytelnikach zdecydowany sprzeciw i poczucie naruszonej sprawiedliwości. Stosunek do młodej żony i jej kochanka badacz określa za to jako neutralny ${ }^{15}$. Jednak warto zauważyć, że to właśnie sposób ukazania przez Mickiewicza postaci kobiety wzbudził w dziewiętnastowiecznych czytelnikach najwięcej emocji.

Ballada z pewnością mogła ówczesnych czytelników zbulwersować za sprawą wyeksponowania w niej kobiecej cielesności i erotyzmu. Dowody na to, jak bardzo Mickiewicz był wówczas dosadny i jak mocno kłócił się z romantyczną estetyką, przedstawił Siemion Łanda. Badacz wymienił w swoim artykule liczne modyfikacje, jakim poddał balladę Antoni Edward Odyniec, przyjaciel poety, adaptując utwór, wedle swego gustu, na grunt warszawski i przygotowując go do pierwszej publikacji w wydawanym przez siebie noworoczniku "Melitele". Choć Czaty wywarły na Odyńcu duże wrażenie, przeszkadzało mu wiele elementów, sprzecznych z jego wyuczonym, delikatnym smakiem. Usunął więc całą ósmą zwrotkę, uznawszy ją za nieprzyzwoitą, oraz wprowadził inne modyfikacje, nadając utworowi charakter bardziej sentymentalny niż romantyczny ${ }^{16}$. Mickiewicz $\mathrm{w}$ zakwestionowanych przez Odyńca fragmentach istotnie nie liczył się z ówczesną normą przyzwoitości. Ukochany kobiety, którego porzuciła dla intratnego małżeństwa, mówi o targającej nim zazdrości: "Co wieczora on będzie, tonąc w puchy łabędzie, / Stary łeb na twym łonie kołysał”. Oczami wyobraźni widzi cielesne zbliżenia między małżonkami. Sam też marzy o bliskości z kobietą: „Bym cię witał westchnieniem i pożegnał życzeniem / Dobrej nocy i długiej pieszczoty!" 17

Mickiewicz w swojej twórczości nie stronił od tematu fizycznej fascynacji między kochankami i erotyki jako niezbywalnego elementu miłosnej relacji. Wystarczy wspomnieć Sonety odeskie czy nawet Ballady $i$ romanse.

\footnotetext{
15 W. Borowy, Improwizacje, utwory towarzyskie i wirtuozerskie, s. 190.

16 S. Łanda, Jak Odyniec redagował "Czaty” Mickiewicza, s. 131-133.

17 A. Mickiewicz, Czaty, w: tegoż, Dzieła wszystkie, wiersze 1817-1825, t. 1, cz. 2, oprac. C. Zgorzelski, Wrocław 1971, s. 64.
} 
W Romantyczności Karusia wspomina nocne spotkania z ukochanym ukrywane przed macochą, Świtezianka kusi strzelca w jak najbardziej cielesny sposób. Tam erotyzm pojawiał się jednak $\mathrm{w}$ innym otoczeniu problemowym - w aurze metafizycznej i etycznej, które tłumiły erotyczne treści, odsuwały od nich uwage poety i odbiorcy. W Czatach natomiast autor skoncentrowany jest na świecie międzyludzkim, relacjach między bohaterami i ich gwałtownych emocjach. Puste małżeńskie łoże pokazane na początku utworu to znak, że erotyka będzie stanowiła kluczowy jego aspekt.

Warto tu zastanowić się nad romantycznym wzorem kobiecości i modyfikacjami, jakim został poddany w toku akcji ballady. Pozycja w świecie kobiety widzianej oczami romantyka była znacznie wyższa niż ta, którą znamy z poprzednich epok. German Ritz w artykule Między "gender" a narodem kobiety w polskim romantyzmie albo język płci zaznacza, że w romantyzmie kobiece "ja” zbliża się do ,ja” poetyckiego. Poeta, chcąc doświadczać świata na wszystkich jego poziomach, zbliża się ku kobiecej wrażliwości, pozostając jednak nadal po stronie kultury. Utrwalony zostaje zatem schemat, zgodnie z którym kobiecość sytuuje się poza jej obrębem, w obszarach fascynującej „dzikości”. Dzieje się tak w programowej balladzie Romantyczność, gdzie narrator potrafi rozszerzyć swoje możliwości/kompetencje pojmowania świata o emocjonalne doświadczenia dziewczyny, pochodzącej z innej warstwy społecznej, a do tego dotkniętej szaleństwem, przez co nie odczuwa wobec niej pogardy, jak starzec, któremu łatwo przychodzi zaklasyfikowanie Karusi jako obłąkanej, a w konsekwencji niewartej współczucia ${ }^{18}$. Podobnie bohaterka Czatów oglądana z perspektywy osoby obdarzonej poetycką wrażliwością będzie inna od tej, na którą pada wzrok pełen nienawiści czy poczucia wyższości.

Żona wojewody widziana oczyma narratora reprezentuje najbardziej charakterystyczny w poezji początku wieku XIX model kobiecego wizerunku. Zespół cech typowych dla romantycznej kochanki został zawarty w sposobie jej przedstawienia. $\mathrm{W}$ toku opowiadania kobieta pojawia się jako postać jaśniejąca w ciemnym ogrodzie. Narrator, opisując ją, używa literackiego, nacechowanego dodatnio, kojarzącego się ze świętością słowa "niewiasta”. Biały strój i wygląd zewnętrzny - „puchy warkoczy”, „usta rumiane”, „lica różane", nadają jej wygląd idealnej kochanki, znanej również z wcześniejszej twórczości Mickiewicza. Jej sytuacja życiowa jest jednak bardziej skomplikowana niż w przypadku innych bohaterek romantycznych ballad, a może

18 G. Ritz, Między "gender" a narodem - kobiety w polskim romantyzmie albo język płci, „Postscriptum" 2006, nr 2, s. 71-72. 
tylko została dokładniej zarysowana. Bohaterka Czatów zostawiła mężczyznę, którego kochała i wyszła za dużo starszego, ale bogatego wojewodę. Niespełniona miłość to jeden z ulubionych tematów romantyków, ale gdy zwykle koncentrowano się na cierpieniu osamotnionego, nieszczęśliwego i zranionego kochanka, to w „balladzie ukraińskiej” zastanawiająca jest kobieta, jej bezradność wobec mężczyzn i świata emocji. Wszyscy trzej męscy bohaterowie ballady mają nad nią władzę. Wojewoda jako mąż i ten, który zapewnił jej dobrobyt materialny, domaga się, co oczywiste, wierności, ale w przypadku zdrady ośmiela się decydować o życiu i śmierci żony. Kochanek, powołując się na łączące ich uczucie, nakłania ją do uległości, a kozak, jako wyznaczony do wykonania zabójstwa, ma sposobność zadecydować o tym, czy odebrać życie kobiecie, czy ją ocalić. Niewątpliwie młoda żona przez swoje złe wybory i niekonsekwentne zachowanie sama przyczyniła się do zaistniałej sytuacji. Najpierw złamała naturalne prawo łączące młodych ludzi miłością. Skusiła się na bogactwo wojewody. Potem z kolei złamała przysięgę małżeńską i wpadła w ręce mściwego starca. Mickiewicz w usta kochanka wkłada słowa pełne wyrzutu: „On nie kochał, nie jęczał, tylko trzosem zabrzęczał, / Tyś mu wszystko przedała na wieki"19. O jej winie czytelnik dowiaduje się z ust zawiedzionego kochanka, kobieta nie mówi nic na swoją obronę. To milczenie świadczy o jej bezradności i bezwolności.

Schadzka kochanków w pierwszej chwili wygląda bardzo niewinnie. Podobna jest do wszystkich innych spotkań młodych, których połączyło uczucie, a rozdzieliły prawa rządzące światem, uniemożliwiając stworzenie trwałego związku między zakochanymi. Kobieta stara się dystansować od ukochanego, powstrzymywać od fizycznego kontaktu. Dopiero pod wpływem słów mężczyzny ulega mu, poddając się wzbierającym w niej emocjom. Podobna postawa nie mogła być nagrodzona, gdyby utwór znalazł się wśród debiutanckich ballad poety. Wystarczy przypomnieć, co spotkało strzelca ze Świtezianki, który złamał słowo dane ukochanej. Kilka lat wcześniej w balladach Mickiewiczowskich natura karała okrutnie podobne przewinienia. Ziemia powinna więc rozstąpić się i pochłonąć wszystkich, łącznie ze zdradzonym ukochanym. W Czatach jest inaczej. Zdrada w tej balladzie nie stanowi problemu moralnego. Osoba mówiąca w wierszu tak buduje narrację, aby nie wzbudzić w czytelniku antypatii do młodej kobiety - wiarołomnej żony, daleka jest od nagannej oceny jej postępowania. Patrzący z romantyczną wrażliwością nie może potępić istoty tak bezradnej wobec świata, zdominowanego

19 A. Mickiewicz, Czaty, s. 64. 
przez mężczyzn. Można powiedzieć, że spojrzenie Mickiewicza na kobietę zatrzymało się $\mathrm{w}$ dziwnym momencie między patriarchalnym pobłażaniem, jeśli nie lekceważeniem, a nowoczesnym dążeniem do zmiany jej pozycji w świecie. Poeta zdaje się dostrzegać i rozumieć kobiece słabości wynikające z gwałtowności uczuć, chęci posiadania bezpieczeństwa materialnego. Jakby od słabej płci nie należało wymagać zachowań ponad siły.

Sposób ukazania kobiety i oddalenie od niej odpowiedzialności za rozgrywające się wydarzenia wynika $\mathrm{z}$ ewolucji ballady $\mathrm{w}$ stronę realizmu. W „balladzie ukraińskiej” człowiek nie stoi wobec prawd moralnych, uosobionych przez siły przyrody, bezwzględnie karzące występki przeciw naturze. Zamiast tego pozostaje zagubiony wśród niepojętych afektów i silnych emocji. Według słów Ireneusza Opackiego, najważniejszym wyznacznikiem balladyczności jest przedstawienie zdarzenia niezwykłego ${ }^{20}$. W interpretowanym tu tekście przesunięciu uległ obszar występowania i ujawniania się niezwykłości, nie odnosi się ona już do sfery metafizyki i zjawisk nadprzyrodzonych, lecz uzewnętrznia się w przeżyciach bohaterów, zagadkowych dla nich samych. Widać tę siłę afektu - trudnego do zdefiniowania chwilowego stanu wewnętrznego - w zachowaniu wojewody, kiedy biegnie do sypialni żony. A przede wszystkim widać w zachowaniu kozaka. Wbrew rozkazowi wojewody Naum nie tylko nie zabija kochanków, lecz strzela do samego rozkazodawcy. Czy sprzeciwia się wojewodzie, odmawiając prawa do zemsty zdradzonemu mężowi? Słowa kozaka nie wskazują na to, że darzy żonę swojego pana szacunkiem. On i wojewoda tworzą front przeciwko niej, z ust obu pada pogardliwe słowo „dziewka”, które oznacza kobietę niezamężną ze stanu chłopskiego.

Dlaczego więc Naum ocala kobietę i jej kochanka, a zabija wojewodę? Dotąd interpretatorzy Czatów niewiele miejsca poświęcili postaci niepokornego sługi. Kleiner nadał mu jedynie funkcję narzędzia $w$ rękach wymierzającej sprawiedliwość natury ${ }^{21}$. Małgorzata Stachurka wspomina Nauma w kontekście odniesień do romantycznej ludowości, podkreśla ważną rolę postaci w Puszkinowskim przekładzie, ale pomija jej rangę $\mathrm{w}$ oryginalnym dziele ${ }^{22}$. A wypada zauważyć, że tylko tego bohatera narrator wyróżnia nazwą własną („I zawołał kozaka Nauma”). Jedynie kozak posiada imię, co od razu zawiązuje nić sympatii między nim a czytelnikiem. Nauma poznajemy

\footnotetext{
20 C. Zgorzelski, Wstęp, w: Ballada polska, oprac. C. Zgorzelski, I. Opacki, Wrocław 1962, s. XLVI.

21 J. Kleiner, Dalsze zdobywanie nowych terenów artyzmu, s. 161.

22 M. Stachurka, Znów o puszkinowskich przekładach ballad Adama Mickiewicza, „Acta Polono-Ruthenica" 2008, t. 13, s. 187-188.
} 
jako sługę wojewody, co do którego ten nie ma wątpliwości, że posłusznie wykona rozkaz. Staje się inaczej. Mimo, że najpierw kozak zdaje się bez szemrania spełniać wolę swego pana, w pewnym momencie wyłamuje się z zaplanowanego przez wojewodę scenariusza:

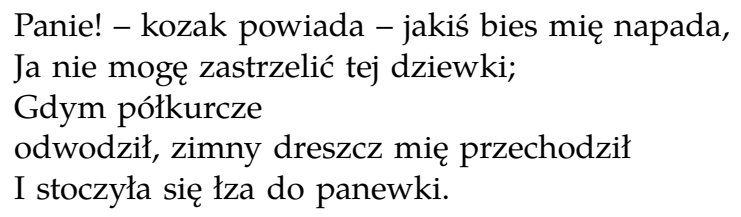

Ciekawy jest sposób, w jaki Naum tłumaczy swoją odmowę zabójstwa. Nie twierdzi, że nie chce tego uczynić, lecz że jakaś niepojęta siła mu nie pozwala „zastrzelić tej dziewki”. Być może kozaka ogarnęła litość, lecz zaskoczyła go tak bardzo, że przypisał ją mocom diabelskim. Prawdopodobnie uważał, że niewierna żona zasługuje na karę, jaką chce jej wymierzyć zdradzony mąż. Kozacy to przecież "plemię" okrutne, kierujące się głównie patriarchalnym systemem wartości, w którym nie ma miejsca na przebaczenie i litość, a plamy na honorze należy zmywać krwią. Warto jednak zwrócić uwagę na podobieństwo między sługą i żoną wojewody, ich zależną pozycją. Oboje pozostawali pod tyranią okrutnego despoty. Można przypuszczać, że zdrada kobiety pokazała Naumowi, że możliwy jest sprzeciw wobec władzy pana - pchany kozackim pragnieniem wolności i swobody, uwolnił siebie i parę kochanków od mściwego starca, jemu samemu wymierzając karę. Trwoga wojewody nie była zatem bezpodstawna. Prawdopodobnie rozumiał on, jak nietrwały jest autorytet, który zbudował na przemocy i majątku.

Mikroświat bohaterów ballady został ograniczony do zachowań wywołanych silnymi impulsami wewnętrznymi, prowadzącymi do destrukcji - zdrady i zbrodni. Nieoczekiwanie wszystko to przybiera obrót, który w pewnym sensie, wedle balladowej logiki - można uznać za pomyślne rozwiązanie. Zły wojewoda ginie, kozak, młoda żona i jej kochanek wyzwalają się spod jego władzy. Przynajmniej tak przeżywa końcowy moment czytelnik, zakończenie nie skłania go, by zastanawiał się, jakie z kolei konsekwencje może pociągnąć zabójstwo wojewody. Wystarczy, że zareaguje afektywnie.

Leksykalna warstwa tekstu wskazuje na pierwotność popędów, którymi kierują się postacie ballady. Tytuł Czaty kojarzy się z polowaniem, wprowadza więc odbiorcę $\mathrm{w}$ świat, gdzie istnieje łowca, zwierzyna i przemoc, a wszystkim kieruje instynkt mordu i instynkt przetrwania. Słowem powtarzającym się w tekście ze zwracającą uwagę częstotliwością jest „łeb”. Znalazło się ono wśród sześciu tysięcy haseł odnotowanych w Słowniku języka 
polskiego Samuela Bogumiła Lindego, gdzie na temat „łba” pada stwierdzenie: „Ani poeta, ani mówca nie użyje łba w poważnej mowie” ${ }^{23}$. Wyraz zaklasyfikowany został do zasobów języka potocznego, autor słownika kategorycznie wykluczył możliwość wykorzystania go w tekstach literackich. Negatywne konotacje słowa wynikają z jego dehumanizujących właściwości. Kto ma "łeb", zostaje zrównany ze zwierzęciem. Mickiewicz nie pierwszy raz pozwolił sobie na łamanie zasady stosowności, używając wyrazu nie pasującego estetycznie do konwencji poetyckiej. Użycie go odnotowano już w czasach kowieńskich, kiedy młody poeta, narzekając na swój los, mówił o „żmudzkich łbach"; co prawda nie w utworze poetyckim, ale przykład ten ilustruje pewne upodobanie Mickiewicza do wymienionego słowa. O „łbie” w "balladzie ukraińskiej" mówi dwukrotnie wojewoda. Raz ma na myśli kochanka żony, potem określa w ten sposób głowę sługi. Trzeci raz słowo wypowiada narrator w ostatnim wersie: „I ugodził w sam łeb - wojewody”. Kto pełni $\mathrm{w}$ utworze rolę zwierzyny i komu należy się największa pogarda? Zdaje się, że decydujący jest osąd narratora. Tak jak w balladzie Romantyczność rozum nie stanowi tu wartości wzbogacającej człowieczeństwo. Wojewoda zwierzęce odruchy okala świadomym, racjonalnym działaniem, którego podstawę stanowi chęć utrzymania despotycznej władzy. Tylko wojewoda potrafi w rozumowy sposób okiełznać swój afekt i wyprowadzić z niego plan zemsty. Kobieta, jej kochanek i Naum to postacie, które nie radzą sobie z intensywnością swojego przeżywania.

Balladowym światem Czatów władają afekty, nie ma trwałych uczuć. Mówi się o miłości, ale wiadomo, że przygasiła ją żądza materialnego posiadania. Z kolei małżeńska wierność przegrała $\mathrm{z}$ namiętnością. $\mathrm{W}$ balladzie nie istnieje wyższy, duchowy wymiar rzeczywistości. Wszystkie uczucia połączone są z cielesnością bohaterów, z krzywdami, które jedni zadają drugim. Kozakiem na chwilę zawładnęła litość, ale on sam przypisał ją siłom piekielnym. Nie litość pokierowała ręką Nauma, kiedy strzelił do wojewody. Skłoniła jedynie sługę do wypowiedzenia na głos niechęci do ukarania wiarołomnej żony, jego słowa zostały jednak brutalnie zlekceważone, a to wywołało w kozaku bunt, który popchnął go do zabójstwa wojewody.

Kiedy podejmowano lekturę Czatów podporządkowaną problematyce gatunkowej, dostrzegano przede wszystkim eksperymenty z wersyfikacją czy zamysł stylizacyjny. Zejście na poziom analizy pozycji narratora i relacji między bohaterami pozwala na ich odczytanie jako wypowiedzi na temat afektów, których siła decyduje o ludzkich decyzjach, a nad którymi nie da się zapanować.

23 S.M. Linde, Stownik języka polskiego, t. 1, cz. 2, Warszawa 1808, s. 1240. 


\section{Bibliografia}

Borowy Wacław (1999), Improwizacje, utwory towarzyskie i wirtuozerskie, w: W. Borowy, O poezji Mickiewicza, wyd. 2 uzup., Lublin: Towarzystwo Naukowe Katolickiego Uniwersytetu Lubelskiego.

Ciechanowska Zofia [oprac.] (1963) Niemiecka ballada romantyczna, Wrocław: Zakład Narodowy im. Ossolińskich.

Cysewski Kazimierz (1987), O „Balladach i romansach” Mickiewicza: interpretacje, Słupsk: Wyższa Szkoła Pedagogiczna w Słupsku.

Dopart Bogusław (1992), Mickiewiczowski romantyzm przedlistopadowy, Kraków: Universitas.

Janion Maria (2007), Gorączka romantyczna, wyd. 2, Gdańsk: Słowo/obraz terytoria.

Kleiner Juliusz (1997), Dalsze zdobywanie nowych terenów artyzmu, w: J. Kleiner, Mickiewicz: dzieje Konrada, wyd. 2 popr., t. 2, cz. 1, Lublin: Towarzystwo Naukowe Katolickiego Uniwersytetu Lubelskiego.

Linde Samuel Bogumił (1808), Słownik języka polskiego, t. 1, cz. 2, Warszawa.

Łanda Siemion (1982), Jak Odyniec redagował "Czaty” Mickiewicza: $z$ "Kroniki życia i twórczości Mickiewicza: 1824-1829”, "Pamiętnik Literacki”, z. 1/2, s. 225-235.

Mickiewicz Adam (1962), Adama Mickiewicza listy nie objęte ostatnim wydaniem ksią̇kowym, zebrał i oprac. S. Pigon, „Pamiętnik Literacki”, z. 3, s. 227-252.

Mickiewicz Adam (1972), Dzieła wszystkie, wiersze 1825-1829, t. 1, cz. 2, oprac. C. Zgorzelski, Wrocław: Zakład Narodowy im. Ossolińskich.

Nycz Ryszard (2015), Wstęp w: Kultura afektu - afekty w kulturze. Humanistyka po zwrocie afektywnym, red. R. Nycz, A. Łebkowska, A. Dauksza, Warszawa: Instytut Badań Literackich PAN, s. 7-24.

Piwińska Marta (1984), Miłość romantyczna, Kraków: Wydawnictwo Literackie.

Pluta Paweł (2017), Polska ballada gotycka, Warszawa: Instytut Badań Literackich PAN.

Pszczołowska Lucylla (2001), Potęga metrum. O puszkinowskim przekładzie „Czat”, „Pamiętnik Literacki", z. 3, s. 171-177.

Ritz German (2006), Między "gender" a narodem - kobiety w polskim romantyzmie albo język ptci, „Postscriptum”, nr 2, s. 66-80.

Sarnowska-Temeriusz Elżbieta (1980), O „katharsis” - raz jeszcze, „Pamiętnik Literacki", z. 4, s. 423-434.

Sawrymowicz Eugeniusz (1956), Drobiazgi Mickiewiczowskie, „Pamiętnik Literacki”, t. 47, Zeszyt specjalny, s. 423-434.

Sokalska Małgorzata (2009), Opera a dramat romantyczny, Mickiewicz - Krasiński - Stowacki, Kraków: Wydawnictwo Uniwersytetu Jagiellońskiego.

Stachurka Małgorzata (2008), Znów o puszkinowskich przekładach ballad Adama Mickiewicza, "Acta Polono-Ruthenica”, t. 13, s. 181-192.

Stefanowska Zofia (1976), Próba zdrowego rozumu. Studia o Mickiewiczu, Warszawa: Państwowy Instytut Wydawniczy. 
Szczeglacka-Pawłowska Ewa (2015), Romantyzm „brulionowy”, Warszawa: Wydawnictwo Uniwersytetu Kardynała Stefana Wyszyńskiego.

Witkowski Michał (1956), Dookoła zagadki steblowskiej, „Pamiętnik Literacki”, t. 47, Zeszyt specjalny, s. 349-395.

Zgorzelski Czesław (1962), Wstęp, w: Ballada polska, oprac. C. Zgorzelski, I. Opacki, Wrocław: Zakład Narodowy im. Ossolińskich, s. III-LXXXV.

\title{
Driving Force of Affects: Adam Mickiewicz's Ballad Czaty
}

\begin{abstract}
The article analyzes the ballad Czaty by Adam Mickiewicz, which has so far received little critical attention. If it was discussed, though, the reason was merely its experimental verse form of the anapaest and the work's stylistic merit. Aiming to re-interpret Mickiewicz's poem, the author of the article concentrates on the narratorial voice and the connections between the literary characters (the voivode, his young wife, the lover, and the voivode's Cossack servant-Nauman). She also underscores the driving force behind the unfolding events. The reading reveals that the characters act upon sudden affective reactions which they can hardly control.
\end{abstract}

Keywords: Polish poetry, Romanticism, ballad, affect, emotions 